\title{
Introduction of Hydrogen produced by Renewable Energy into the Peruvian Electricity Market
}

\author{
Johnny Nahui-Ortiz, Ph.D. ${ }^{1}$ \\ ${ }^{1}$ National University of Engineering - UNI, Peru, jnahuio@uni.edu.pe
}

\begin{abstract}
Hydrogen energy is considered as the fuel of the future and it is already being introduced in the energy markets of more developed regions; however, it remains uncertain its potential impact in developing countries such as Peru. On the other hand, the Peruvian energy sector has being growing during the last decade but electricity production has also been shifting from a renewable energy source, such hydropower toward a fossil fuel namely natural gas. The paper examines the potential for hydrogen production from solar and wind power and also the potential substitution of natural gas by hydrogen produced by renewable energy sources. A potential carbon emission reduction is also estimated as a preliminary approach.
\end{abstract}

Keywords - Hydrogen Production, Renewable Energy / Peruvian Market / Electricity Generation / Carbon Emissions

\section{INTRODUCTION}

Energy is the very lifeblood of today's society and economy. Our work, leisure, and our economic, social and physical welfare all depend on the sufficient, uninterrupted supply of energy. Yet we take it for granted - and energy demand continues to grow, year after year. Traditional fossil energy sources such as oil are ultimately limited and the growing gap between increasing demand and shrinking supply will, in the not too distant future, have to be met increasingly from alternative primary energy sources [1].

On the technology front, hydrogen, a clean energy carrier that can be produced from any primary energy source, and fuel cells which are very efficient energy conversion devices, are attracting the attention of public and private authorities. Hydrogen and fuel cells, by enabling the so-called hydrogen economy, hold great promise for meeting in a quite unique way, our concerns over security of supply and climate change [1].

Even though all of the above has already been acknowledged by development regions, such Europe, there is still uncertainty as to whether or not hydrogen energy may be also an alternative for developing countries.

\section{ENERGY SECTOR OF PERU}

The energy sector in Peru has evolved during the last few years due to a continuous economic growth from 2001 to 2015, increasing at an annual rate of above $7.5 \%$. [4]

Digital Object Identifier (DOI): http://dx.doi.org/10.18687/LACCEI2018.1.1.481 ISBN: 978-0-9993443-1-6

ISSN: $2414-6390$

\section{A. Production and Reserves}

The energy production in Peru is based on natural gas, hydropower, crude oil, and coal. In 2016, total energy production accounted for around 955 PJ while total energy reserves were established at about $36914 \mathrm{PJ}$. Natural gas is the main primary energy resource used in the country and represents nearly $79 \%$ of total energy production. However, in terms of energy reserves it represents about $54 \%$ of the total [4], as shown in Table I.

TABLE I

ENERGY PRODUCTION AND RESERVES FOR 2016 (TJ)

\begin{tabular}{|c|c|c|c|c|}
\hline Energy Source & Production & $\%$ & Reserves & $\%$ \\
\hline Natural Gas & 753341 & $78.9 \%$ & 19933761 & $54.0 \%$ \\
\hline Crude Oil & 85545 & $9.0 \%$ & 2518249 & $6.8 \%$ \\
\hline Hydropower & 108719 & $11.4 \%$ & 5965666 & $16.2 \%$ \\
\hline Coal & 7343 & $0.8 \%$ & 230960 & $0.6 \%$ \\
\hline Uranium & 0 & 0 & 8265149 & $22.4 \%$ \\
\hline TOTAL & 954948 & $100 \%$ & 36913785 & $100 \%$ \\
\hline
\end{tabular}

\section{B. Energy Consumption}

Energy consumption in Peru includes mainly electricity, hydrocarbons. Also, some biomass consumption is noted. Diesel Oil, which includes 5\% of biodiesel, is the main energy source utilized in the country and accounted for about $32 \%$ in 2016. Also, electricity represented nearly $23 \%$ of the total in that year. Besides, both natural gas and liquefied petroleum gas accounted for around $11 \%$ of the total in each case. It is important to note that there is also a consumption of wood and it is nearly as significant as other energy sources and that amounts to about $11 \%$. Moreover, there is also a consumption of gasoline, blended with ethanol, and accounts for over $10 \%$ [4]. In addition to that, there is also consumption of dung and yareta as energy sources, particular in rural areas of the country, as shown in Table II.

$16^{\text {th }}$ LACCEI International Multi-Conference for Engineering, Education, and Technology: "Innovation in Education and Inclusion", 19-21 July 2018, Lima, Peru. 
TABLE II

ENERGY CONSUMPTION BY SOURCES FOR 2016 (TJ)

\begin{tabular}{|l|c|c|l|c|c|}
\hline Energy Source & TJ & $\%$ & Energy Source & TJ & $\%$ \\
\hline $\begin{array}{l}\text { Diesel Oil / } \\
\text { Biodiesel }\end{array}$ & 227523 & $31.8 \%$ & $\begin{array}{l}\text { Non energy } \\
\text { products }\end{array}$ & 11229 & $1.6 \%$ \\
\hline Electricity & 163325 & $22.9 \%$ & Fuel Oil & 9687 & $1.4 \%$ \\
\hline Wood & 74797 & $10.5 \%$ & $\begin{array}{l}\text { Dung and } \\
\text { yareta }\end{array}$ & 7174 & $1.0 \%$ \\
\hline LPG & 79569 & $11.1 \%$ & Bagasse & 8665 & $1.2 \%$ \\
\hline Motor Gasoline & 11699 & $1.6 \%$ & $\begin{array}{l}\text { Gasoline / } \\
\text { Alcohol }\end{array}$ & 71982 & $10.1 \%$ \\
\hline $\begin{array}{l}\text { Distributed } \\
\text { Gas }\end{array}$ & 79632 & $11.1 \%$ & Charcoal & 1608 & $0.2 \%$ \\
\hline Kerossene Jet & 43450 & $6.1 \%$ & Coke & 2477 & $0.3 \%$ \\
\hline Coal & 23286 & $3.3 \%$ & Solar Energy & 1391 & $0.2 \%$ \\
\hline \multicolumn{7}{|c|}{ TOTAL } & \multicolumn{7}{|c|}{714510} & $100.0 \%$ \\
\hline \multicolumn{7}{|c|}{ ADDAPTED FROM [4]. }
\end{tabular}

Energy consumption includes mainly transportation, residential, commercial and public, as well as industry and mining sectors. Energy consumption for Transportation sector accounted for around $45 \%$ of total energy consumption in 2016. Also energy consumption for Residential, Commercial and Public sector accounted for around 26\% in the same year. Besides, energy consumption for Industry and Mining sector represented also about 26\% [4], as shown in Table III.

TABLE III

ENERGY CONSUMPTION BY SECTORS FOR 2016 (TJ)

\begin{tabular}{|l|c|c|}
\hline \multicolumn{1}{|c|}{ Sector } & TJ & $\%$ \\
\hline Transportation & 369121 & $45.2 \%$ \\
\hline Residential, Commercial and Public & 209149 & $25.6 \%$ \\
\hline Industry and Mining & 208952 & $25.6 \%$ \\
\hline Agricultural, Agroindustry, and Fishing & 16949 & $2.1 \%$ \\
\hline Non Energy & 13319 & $1.6 \%$ \\
\hline \multicolumn{2}{|c|}{ TOTAL ADDAPTED FROM [4]. } \\
\hline \multicolumn{2}{|c|}{817490} & $100.0 \%$ \\
\hline
\end{tabular}

The following figure shows the participation of different sources and sectors in the energy mix [4].

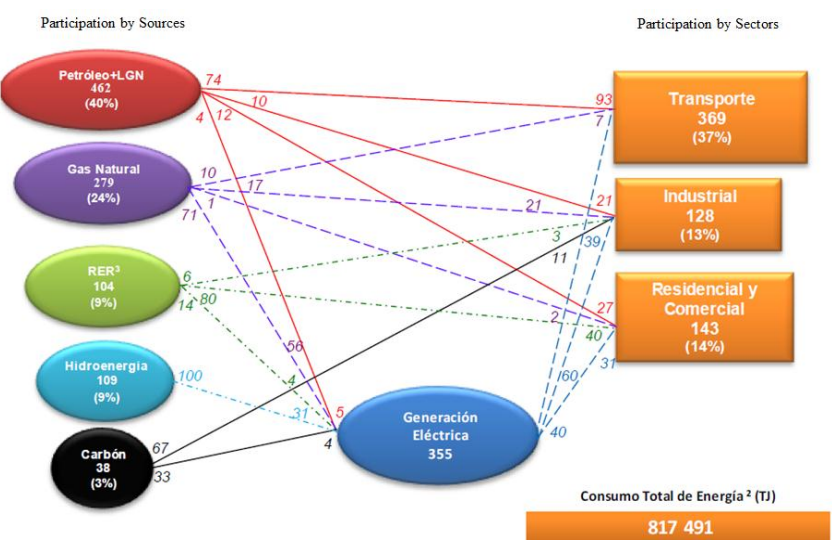

Fig. 1 Peru’s energy mix in P'J for 2016. [4]

\section{Electricity Production}

Electricity production in Peru includes power plants that run on natural gas, hydropower, fuel oil, coal, diesel oil (with $5 \%$ biodiesel added), bagasse, wind, and solar energy. In 2006, around $56 \%$ of electricity was produced by natural gas power plants. Also, hydropower plants participation accounted for nearly $31 \%$ of the total. It is important to mention that almost 15 years ago, hydropower plants participation was over $90 \%$ of the total electricity production. Participation of renewable energies for electricity production is still at an incipient stage and accounted for less than 5\% of the total. Moreover, it should be noted that overall energy efficiency associated with electricity production is around 53\% due to increasing participation of thermal power plants in total production. Also, Transmission and distribution losses represent around 10.6\% of total electricity produced by power plants [4], as shown in Table IV.

TABLE IV

ELECTRICITY PRODUCTION BY SOURCE IN TJ FOR 2016

\begin{tabular}{|l|c|c|}
\hline \multicolumn{1}{|c|}{ Energy Source } & TJ & $\%$ \\
\hline Natural Gas & 199607 & $56.3 \%$ \\
\hline Hydropower & 108719 & $30.7 \%$ \\
\hline Fuel Oil & 6994 & $2.0 \%$ \\
\hline Coal & 12524 & $3.5 \%$ \\
\hline Diesel Oil / Biodiesel & 11048 & $3.1 \%$ \\
\hline Bagasse & 9583 & $2.7 \%$ \\
\hline $\begin{array}{l}\text { Biogas, Wind and } \\
\text { Solar }\end{array}$ & 6068 & $1.7 \%$ \\
\hline \multicolumn{1}{|c|}{ TOTAL } & 354543 & \begin{tabular}{c}
100.0 \\
\hline Generation Losses
\end{tabular} \\
\hline Electricity Production & 168514 & $47.5 \%$ \\
\hline Distribution Losses & 186029 & $52.5 \%$ \\
\hline \multicolumn{2}{|c|}{19731} & $10.6 \%$ \\
\hline
\end{tabular}

ADDAPTED FROM [4].

$16^{\text {th }}$ LACCEI International Multi-Conference for Engineering, Education, and Technology: "Innovation in Education and Inclusion”, 19-21 July 2018, Lima, Peru. 
Also, considering a coefficient of 0,56 tC/MW.h [9] for the electric power system in Peru, total carbon emissions would amount to about 29 million tons per year.

\section{Peak-Time Electricity Dispatch}

With regard to peak-time electricity dispatch, in March 2018, a total peak demand of 6389 MW was registered at 19:30 hrs. At that time, economic electricity dispatch was composed by hydropower $(63 \%)$ and natural gas $(63 \%)$ power plants. Also, at that time, renewable energy production contributed with over $4 \%$ for peak total demand [8], as shown in table $\mathrm{V}$.

TABLE V

ELECTRICITY DISPATCH AT PEAK-TIME DEMAND IN TJ FOR MARCH 2018

\begin{tabular}{|c|c|}
\hline Energy Source & $\%$ \\
\hline Diesel Oil & $0.00 \%$ \\
\hline Fuel Oil & $0.00 \%$ \\
\hline Coal & $0.00 \%$ \\
\hline Natural Gas & $33.36 \%$ \\
\hline Hydropower & $62.55 \%$ \\
\hline Biogás & $0.12 \%$ \\
\hline Bagasse & $0.22 \%$ \\
\hline Solar & $0.00 \%$ \\
\hline Wind & $3.75 \%$ \\
\hline TOTAL & $100.00 \%$ \\
\hline \multicolumn{2}{|c|}{ ADDAPTED FROM [8]. }
\end{tabular}

\section{HYDROGEN ENERGY}

Hydrogen is not another fuel. It has physical and chemical properties very different from the other fuels. It is not a natural resource but it is encountered combined in other compounds such as hydrocarbons or water [2].

Actually hydrogen is an energy carrier which means that it has to be produced from energy resources, containing certain amount of energy once produced [2].

Hydrogen requires a final conversion element which may be a direct or an indirect one. A fuel cell is a direct energy conversion system, transforming chemical energy of hydrogen into electric energy. Internal combustion engines transform the chemical energy of hydrogen into mechanical energy, which may be used to drive a generator or for moving a transportation system [2].

A fuel cell shares common elements with both batteries and internal combustion engines. Thus, fuel cells are similar to batteries due to electrochemical principles that rule both of them, obtaining two devices in direct current (DC). On the other hand, fuel cells differ from batteries in the sense that they do not storage energy. Instead they transform the chemical energy of hydrogen into electricity in a continuous way, terminating electricity production once hydrogen supply is terminated. Such continuous electricity production characteristic is common to internal combustion engine, although they are subject to the Carnot limit and the fuel cell is not [2].

\section{A. Hydrogen Production}

There are various methods for hydrogen production and they can be both centralized and massive squemes as well as decentralized ones [2].

A designation of chemical conversion may be applied to both fossil fuels (coal and hydrocarbons) and renewable energy (biomass). The main processes include: reforming (with water vapor, partial oxidation, auto-thermal reforming), pyrolysis, and gasification [2].

In all of the above process, $\mathrm{CO}_{2}$ is produced in higher or lower levels, and it is feasible its capture. This capture may become necessary if the process is intended to be applied to a fossil fuel in order to achieve an environmental cleaning associated with hydrogen. If the process is applied to biomass the capture of $\mathrm{CO}_{2}$ would produce a negative emission of $\mathrm{CO}_{2}$ although the economic cost may not be justified [2].

Within the above context, renewable energy appears as an attractive alternative for hydrogen production. Even though solar energy most common application is at high temperature, it is also possible to utilize solar photovoltaic modules for low temperature electrolysis production. Also hydrogen production based on wind energy utilizes low temperature electrolysis and it may be considered a feasible technology [2].

Similar to production processes, there are several procedures for hydrogen storage. Hydrogen stores a large quantity of energy per mass unit, but a very small one per volume unit. That is why there is an active field of research focusing on how to increase volumetric density of the procedure [2].

Once hydrogen is stored it is possible that the end user requires a distribution service which is a function of basically both the consumption and the needs [2].

It does not exist a fuel that is exempted from certain risks. In fact, the properties that turn a substance into a good fuel (high heating value) are the same properties that turn it into a potential dangerous substance. As a general rule, the better a fuel is the more the safety measures required to handle it. And hydrogen is not an exemption [2].

The following figure shows potential energy sources for hydrogen production [1]. 


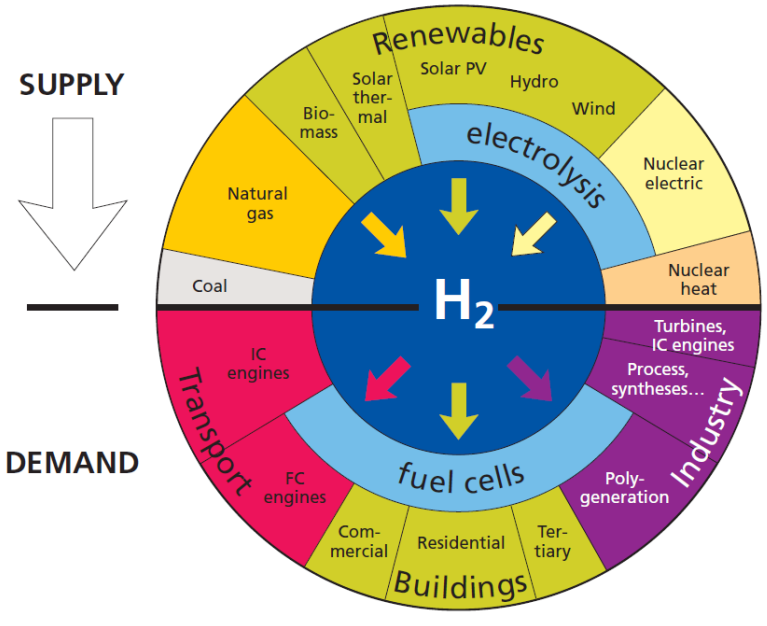

Fig. 2 Hydrogen: primary energy sources, energy converters and applications. [1]

\section{B. Fuel Cell Technology}

There are several criteria for fuel cells classification. A technical one is according to the electrolyte that they use, including: Proton-exchange membrane fuel cell (PEMFC), Alkaline fuel cell (AFC), Phosphoric-acid fuel cell (PAFC), Molten carbonate fuel cell (MCFC), Solid oxide fuel cell (SOFC) [2].

Another criterion could be their working temperature range, including: Low temperature (operating at $80^{\circ} \mathrm{C}$ ), including PEMFC and $\mathrm{AFC}$; Intermediate temperature (operating at $200^{\circ} \mathrm{C}$ ) including $\mathrm{PAFC}$ and High temperature (operating between 650 and $1100^{\circ} \mathrm{C}$ ), including MCFC and SOFC [2].

As a general rule, application of fuel cells of high and medium temperature are more adequate for stationary usages en which the power required ranges from 1 to $100 \mathrm{MW}$ and useful life is estimated at 5 years. On the other hand, fuel cells of low temperature are more adequate for transportation applications, in power range of 10 to $200 \mathrm{~kW}$ and with a vehicle's autonomy between 300 and $500 \mathrm{~km}$. Fuel cells of intermediate temperature can be also used for stationary applications of lower power (up to $10 \mathrm{MW}$ ), and those of low temperature can be used in stationary applications of reduced power (up to $5 \mathrm{~kW}$ ) [2].

The following figure shows different types of fuel cell technologies that may be utilized [1].

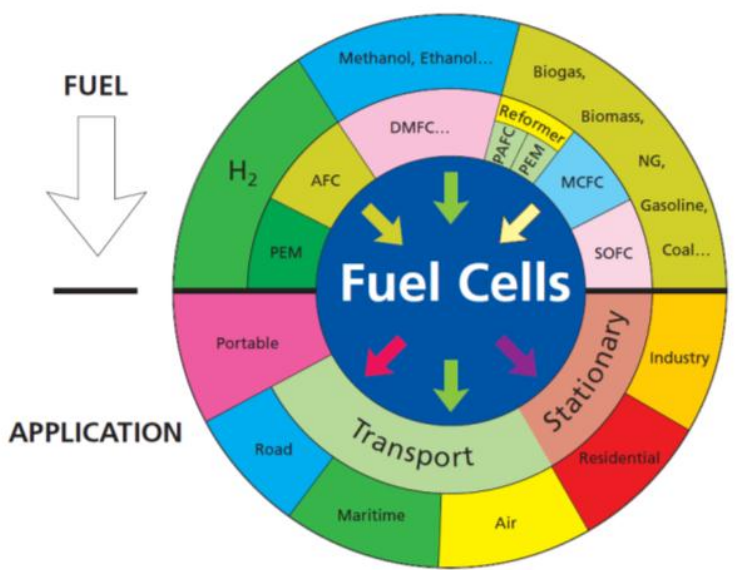

Fig. 3 Fuel cell technologies, possible fuels and applications. [1]

\section{POTENTIAL FOR HYDROGEN ENERGY IN PERU}

\section{A. Potential for Hydrogen Production from Solar Energy}

Peru has a high potential for solar power utilization. Since 2012, five solar power plants have already been operating showing capacity factors over $30 \%$. According to [5], solar irradiation levels reach almost $7 \mathrm{~kW} . \mathrm{h} / \mathrm{day}-\mathrm{m}^{2}$ in the southern part of the country, wherein four $20-\mathrm{MWp}$ and one $16-\mathrm{MWp}$ have been installed through a bidding process that was conducted early in 2010. Also, $185 \mathrm{MWp}$ more of solar power capacity is expected to be installed in 2018.

\section{B. Potential for Hydrogen Production from Wind Energy}

With regard to wind power utilization, Peru has also a high potential. Since 2014, three wind power plants have already been operating showing capacity factors over $60 \%$. According to [6], wind velocity levels reach almost $11 \mathrm{~m} / \mathrm{s}$ at about $80 \mathrm{~m}$ height in the mid-southern part of the country, wherein one 32-MW and another 98-MW power plants have been installed through the same bidding process that was conducted early in 2010. Also, one 30-MW and another 80MW power plant have been operating in the northern part of the country with wind speeds over $10 \mathrm{~m} / \mathrm{s}$, also at $80 \mathrm{~m}$ height. In addition to that, $162 \mathrm{MWp}$ more of wind power capacity is expected to be installed in 2018 .

\section{Potential for Substitution of Natural Gas by Hydrogen} Hydrogen is being pursued as a sustainable energy carrier for fuel cell electric vehicles (FCEVs) and as a means of storing renewable energy at utility scale. Hydrogen can also be used as a fuel in stationary fuel cell systems for buildings, backup power, or distributed generation. Blending hydrogen into the existing natural gas pipeline network has been proposed as a means of increasing the output of renewable energy systems such as large wind farms. If implemented with relatively low concentrations, less than $5 \%-15 \%$ hydrogen by volume, this strategy of storing and delivering renewable

$16^{\text {th }}$ LACCEI International Multi-Conference for Engineering, Education, and Technology: "Innovation in Education and 
energy to markets appears to be viable without significantly increasing risks associated with utilization of the gas blend in end-use devices (such as household appliances), overall public safety, or the durability and integrity of the existing natural gas pipeline network [3].

Adding hydrogen to natural gas can significantly reduce greenhouse gas emissions if the hydrogen is produced from low-carbon energy sources such as biomass, solar, wind, nuclear, or fossil resources with carbon capture and storage (CCS). Any social or environmental benefits associated with sustainable hydrogen pathways could arguably be attributed to natural gas with a hydrogen blend component in proportion to the hydrogen concentration [3].

For illustration purposes, the potential for substitution of natural gas by hydrogen will be estimated at a blending proportion of $10 \%$. Thus, considering the total natural gas consumed for electricity production in 2016 as $199607 \mathrm{TJ}$, the potential for substitution using hydrogen would account for about 19961 TJ. Now, considering an estimated coefficient of $15 \mathrm{tC} / \mathrm{TJ}$ for natural gas, carbon emissions could be reduced in nearly 300000 tons per year.

However, in Peru, according to Law Decree 1002, it is expected that renewable energy production should achieve up to $5 \%$ of total electricity production [7]. Thus, considering total electricity production in 2016 as 186029 TJ, renewable energy could produce electricity up to 9301 TJ. Therefore, there is still room for further development of renewable energy projects for electricity production.

\section{CONCLUSIONS}

The Peruvian energy sector has being growing during the last decade but electricity production has also been shifting from a renewable energy source, such hydropower toward a fossil fuel namely natural gas. In 2016, natural gas contributed in $56 \%$ to electricity production while hydropower contributed only with $31 \%$.

According to local regulations, established in 2008, it should be expected that renewable energies can contribute with up to $5 \%$ of total electricity production. At present, that target has not been achieved.

Peru has high potential for utilization of renewable energy for hydrogen production. Solar power plants are operating and capacity factors over $30 \%$ while wind power plants are operating at capacity factors of nearly $60 \%$.

It is estimated that if hydrogen produced by renewable energy could be blended into natural gas pipelines a potential carbon emission reduction of 300000 tons per year could be accomplished.

\section{REFERENCES}

[1] European Commission, "Hydrogen energy and fuel cells, a vision of our future", Directorate-General for Research, 2003.
[2] J. Linares and B. Moratilla, "El Hidrógeno y la energía, análisis de situación y prospective de nuevas Fuentes tecnológicas energéticas". Asociación Nacional de Ingenieros del ICAI, 2007.

[3] National Renewable Energy Lab, "Blending Hydrogen into Natural Gas Pipeline Networks: A review of key issues". Technical Report NREL/TP5600-51995, 2013.

[4] Ministerio de Energía y Minas - MINEM, "República del Perú, Balance Nacional de Energía 2016”. Dirección General de Eficiencia Energética, 2018.

[5] Ministerio de Energía y Minas - MINEM, "Atlas Solar del Perú". 2003.

[6] Ministerio de Energía y Minas - MINEM, "Atlas Eólico del Perú", 2016.

[7] RER Decreto Legislativo 1002, "Promoción de la inversión para la generación de electricidad con el uso de energías renovables", 2008.

[8] SINAC-COES, "Estadística de Operación 2016".

[9] The World Bank - Carbon Finance Unit, "Poechos I Project", 2018. 